\title{
Isolation and characterization of bacteria producing hydrolase enzymes from two moroccan hypersaline environments
}

\author{
AbdessamadEl berkaoui ${ }^{1,2^{*}}$,AichaAit alla ${ }^{2}$, AbdellatifMoukrim $^{2}$, FaissalEl filali ${ }^{1}$, \\ SaidHanoune ${ }^{1}$, andNaima Boum'handi ${ }^{1}$. \\ ${ }^{1}$ Laboratory of Microbiology, Seafood Processing and Technology Centre (CSVTPM), National \\ Research Institute of Marine Fisheries (INRH), BP: 1050, Agadir- Morocco. \\ ${ }^{2}$ Laboratory " Aquatic Systems: Marine and Continental Environment, University Ibn Zohr, Faculty \\ of Sciences, BP: 8106, Agadir, Morocco.
}

\begin{abstract}
Halophilic bacteria are a group of microorganisms living in saline environments and in some cases need the salinity to survive. Furthermore,these bacteria species have the potential for interesting and promising applications. In fact, this is due not only to their ability to adapt to extreme physico-chemical conditions but also because many of them they produce interesting substances for the industry such as extracellular hydrolytic enzymes. The present study aims to isolate and characterize halophilic bacteria producing hydrolase enzymes from twosalinesin Sidi Moussa-Oualidia complex (Morocco) and to screen their potential to produce hydrolase enzymes. In this study, 15 halophilic bacteria were identified and analyzed for their ability to produce extracellular enzymes. The phylogenetic analysis based on 16S rDNA sequencing indicated that the 15 isolated strains belong to the genera Bacillus, Oceanobacillus and Virgibacillus. The study of enzymatic activity revealed that all isolates studied were capable of producing at least one extracellular hydrolytic enzyme of which 9 produced amylase, 6 cellulase, 13 DNase, 11 lipase, and 8 protease. In addition to their ability to produce extracellular hydrolytic enzymes, our isolates have demonstrated their potential adaption to extreme Physico-chemical conditions. These properties could allow them to be used for many industrial applications.
\end{abstract}

\section{Introduction}

Halophilic and halotolerant bacteria are a group of microorganisms living in saline environments and in some cases need the salinity to survive. To maintain cell structure and function in high salt concentration, these bacteria have developed various biochemical strategies [1].Indeedmost halophilic and halotolerant bacteria studied to date are attracting interest for their capacity to produce compounds with high potential in industrial processes,

*Corresponding author:a.elberkaoui@yahoo.fr 
such as extracellular hydrolytic enzymes[2, 1], including protease, amylase, lipase, cellulase, and DNase. These enzymes have very diverse potential uses in different biotechnological and industrial applications such as food, biomedical, pharmaceutical, detergents, cosmetic and textile industries[3-5]. Moreover, research on the biotechnological potential of halophilic bacterial enzymes is increasing because of their stable activity at a high salt concentration as well as at high temperature and alkaline $\mathrm{pH}$.These properties would allow halophilic enzymes to be used in industrial processes requiring harsh conditions[6-8]. However, to date,very few halophilic enzymes have been used in biotechnological applications or industrial processes compared to enzymes from alkalophilic and thermophilic bacteria[9]. The Sidi Moussa-Oualidia complex is an important Moroccan wetland including several hypersaline environments: Sidi El Abed salines,Sidi M'bareksalines, Sidi Moussa lagoon and salines, andOualidia lagoon and salines. It is located on the Atlantic coast of Morocco, in the province of El Jadida. Accordingly, it was designated as a wetland of international importance under the Ramsar Convention in 2005. However,until now, no environmental study has focused on the phylogenetic diversity of halophilic bacteria in the Sidi Moussa-Oualidia complex. Therefore, the present study aimed to isolate and characterize the halophilic bacteria producing hydrolase enzymes from the Sidi El Abed and Sidi Moussa salines.

\section{Materials and methods}

\subsection{Study area}

Sediment samples were collected from two sites in the Sidi El Abed $\left(33^{\circ} 02^{\prime} \mathrm{N}, 08^{\circ} 42^{\prime} \mathrm{W}\right)$ and Sidi Moussa $\left(33^{\circ} 01^{\prime} \mathrm{N}, 08^{\circ} 43^{\prime} \mathrm{W}\right)$ salines located on the Atlantic coast of Morocco(Figure 1).

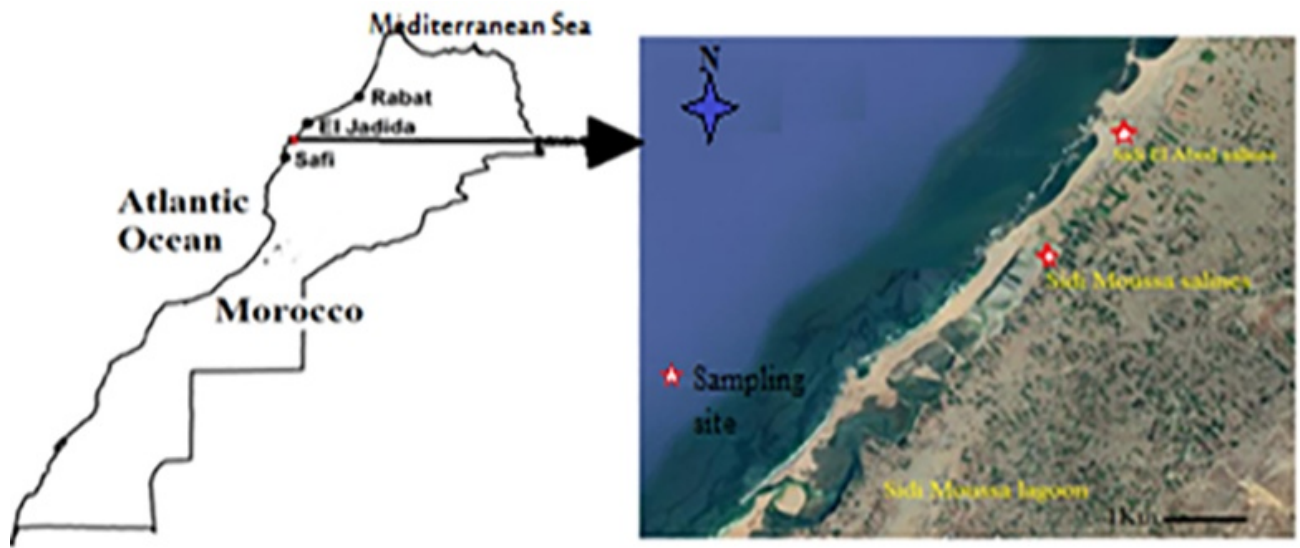

Figure 1:Geographical location of the Sidi El Abed and Sidi Moussa salines with the sampling sites (Google Earth image).

\subsection{Isolation of bacterial strains}

$15 \mathrm{~g}$ of each sediment sample was collected and homogenized in $15 \mathrm{~mL}$ of sterilized saltwater with $5 \% \mathrm{NaCl}$ and serially diluted up to $10^{-4}$ dilution. For the isolation of the halophilic bacteria, $0.1 \mathrm{ml}$ of each serially diluted sample was plated on one of five different salt concentrations $(2 \%, 5 \%, 10 \%, 15 \%$ and $20 \%)$ in the Columbia medium containing the following composition (g per L): polypeptones (17); pancreatic heart peptone (3); corn starch (1); sodium chloride (5); yeast extract (3); agar (13.5); $\mathrm{pH} 7.3+/-$ 
0.2 (Biokar Diagnostics, Beauvais, France) and incubated at $30^{\circ} \mathrm{C}$ for 48 h. 192 Distinct colonies were selected and subcultured several times on Columbia agar to obtain high purity. The isolates were stored in $20 \%$ of glycerol at $-80^{\circ} \mathrm{C}$ for further analysis.

\section{$2.316 \mathrm{~S}$ rDNA sequencing and phylogenetic analysis}

Fifteen strains were randomly selected according to their phenotypic, biochemical and physicochemical characteristics and to their capacity to synthesize extracellular hydrolytic enzymes. The genomic DNA of these strains was extracted and purification by Genomic DNA Mini Kit (Invitrogen, USA) following the procedure suggested by the manufacturer.The 16S rRNA was amplified using PCR Supermix Kit (Invitrogen, USA) and the universal primers FD1 (AGAGTTTGATCCTGGCTCAG) and rP2(ACGGCTACCTTGTTACGACTT)synthesized by Bio Basic Inc[10].The amplification procedure was performed according to the manufacturer's recommendations on the MiniAmp thermal cycler (Applied Biosystems, USA). Sanger sequencing was performed at National Center for Scientific and Technical Research (CNRST, Morocco). Preliminary identifications were realized based on sequence assembly and by query in the NCBI database. Phylogenetic analysis was performed using the software MEGA 7 [11]. The partial sequences of the $16 \mathrm{~S}$ rDNA gene have been deposited in the NCBI database under the following accession numbers MZ317300-MZ317314.

\subsection{Morphological and physiological characterization}

The morphological characteristics of the isolates were determined by standard methods [12]. The salt tolerance of the bacterial strains was tested on Columbia agar with $5 \%, 10 \%$, $15 \%$ and $20 \% \mathrm{NaCl}$ and incubated at $30^{\circ} \mathrm{C}$. The $\mathrm{pH}$ effect on isolates was examined by growing them on Columbia agar with a three $\mathrm{pH}$ value (4.5, 7.5 and 9.2) and incubating them at $30^{\circ} \mathrm{C}$. Growth at different temperatures was evaluated on Columbia agar after incubation at 10,30 and $50^{\circ} \mathrm{C}$. the growth was measured by visual observation after incubation for 24 to 72 hours.

\subsection{Determination of extracellular hydrolytic activities}

Screening of strains for extracellular hydrolytic activities was performed as follows: Extracellular cellulase activity was revealed as described by Sadfi-Zouaoui et al [13]. DNase activity was tested according to Jeffries et al [14]. Amylolytic, lipolytic and proteolytic activities were assayed as described by Cowan [15], Sierra [16] and SánchezPorro et al [8] respectively. The halo diameter of hydrolytic activity (Hd) and colony diameter $(\mathrm{Cd})$ of each strain were measured and the difference between $\mathrm{Hd}$ and $\mathrm{Cd}$ was calculated and considered as an estimate of hydrolytic activity (Figure 2).

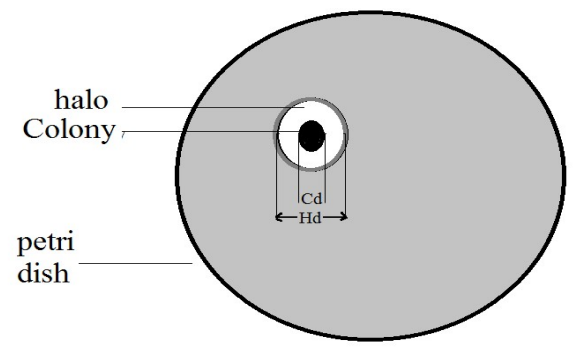

Cd: Colony diameter

Hd: Halo diameter 
Figure 2:Method used to measure hydrolytic activity.

\section{Results and discussion}

\subsection{Identification of bacterial strains.}

Comparative analysis of the $16 \mathrm{~S}$ rRNA partial sequences of the strains isolated from the sediments of Sidi El Abed and Sidi Moussa salterns revealed the following distribution: Bacillus subtilis has four strains, Bacillus licheniformis has three strains, Cytobacillusoceanisediminis(The new name for Bacillus oceanisediminis[17])and Bacillus halotolerans each have two strains, and Bacillus mojavensis, Bacillus aquimaris, Virginibacillussalarius and Bacillus spizenii(Previously considered a subspecies of Bacillus subtilis but was promoted to species status byDunlap et al. [18]) each have one strain (Table 1).The phylogenetic tree constructed byUPGMAmethod, presented in Figure 3 , showed similar results.

This result reveals that Bacillus is the most dominant genus, with 12 strains representing 6 species; the other two genera, Cytobacillus and Virgibacillus, were represented by two and one species, respectively. Therefore,Bacillus is very adapted to saline sediments, as proven by this study.

Table 1: Affiliation of the 16S rRNA gene sequences and accession numbers of isolated halophilic bacteria.

\begin{tabular}{|l|l|l|l|}
\hline $\begin{array}{l}\text { Representative } \\
\text { isolate }\end{array}$ & $\begin{array}{l}\text { Tentative identification based on } \\
\text { nearest neighbor }\end{array}$ & $\begin{array}{l}16 \mathrm{~S} \\
\mathbf{0} \%)\end{array}$ & $\begin{array}{l}\text { senBank } \\
\text { accession } \\
\text { number }\end{array}$ \\
\hline HBFO11 & Virgibacillussalarius & $99.88 \%$ & MZ317305 \\
\hline HBSW27 & Cytobacillusoceanisediminis & $100 \%$ & MZ317311 \\
\hline HBFW7 & Cytobacillusoceanisediminis & $100 \%$ & MZ317310 \\
\hline HBFW2 & Bacillus subtilis & $100 \%$ & MZ317309 \\
\hline HBSO12 & Bacillus subtilis & $100 \%$ & MZ317302 \\
\hline HBFW4 & Bacillus subtilis & $100 \%$ & MZ317313 \\
\hline HBFW17 & Bacillus subtilis & $100 \%$ & MZ317308 \\
\hline HBSO7 & Bacillus spizizenii & $100 \%$ & MZ317301 \\
\hline HBSW4 & Bacillus mojavensis & $100 \%$ & MZ317307 \\
\hline HBSO2 & Bacillus licheniformis & $100 \%$ & MZ317300 \\
\hline HBSO20 & Bacillus licheniformis & $99.69 \%$ & MZ317314 \\
\hline HBFW20 & Bacillus licheniformis & $100 \%$ & MZ317303 \\
\hline HBSO19 & Bacillus halotolerans & $100 \%$ & MZ317312 \\
\hline HBSW29 & Bacillus halotolerans & $100 \%$ & MZ317306 \\
\hline HBFO12 & Bacillus aquimaris & $100 \%$ &
\end{tabular}




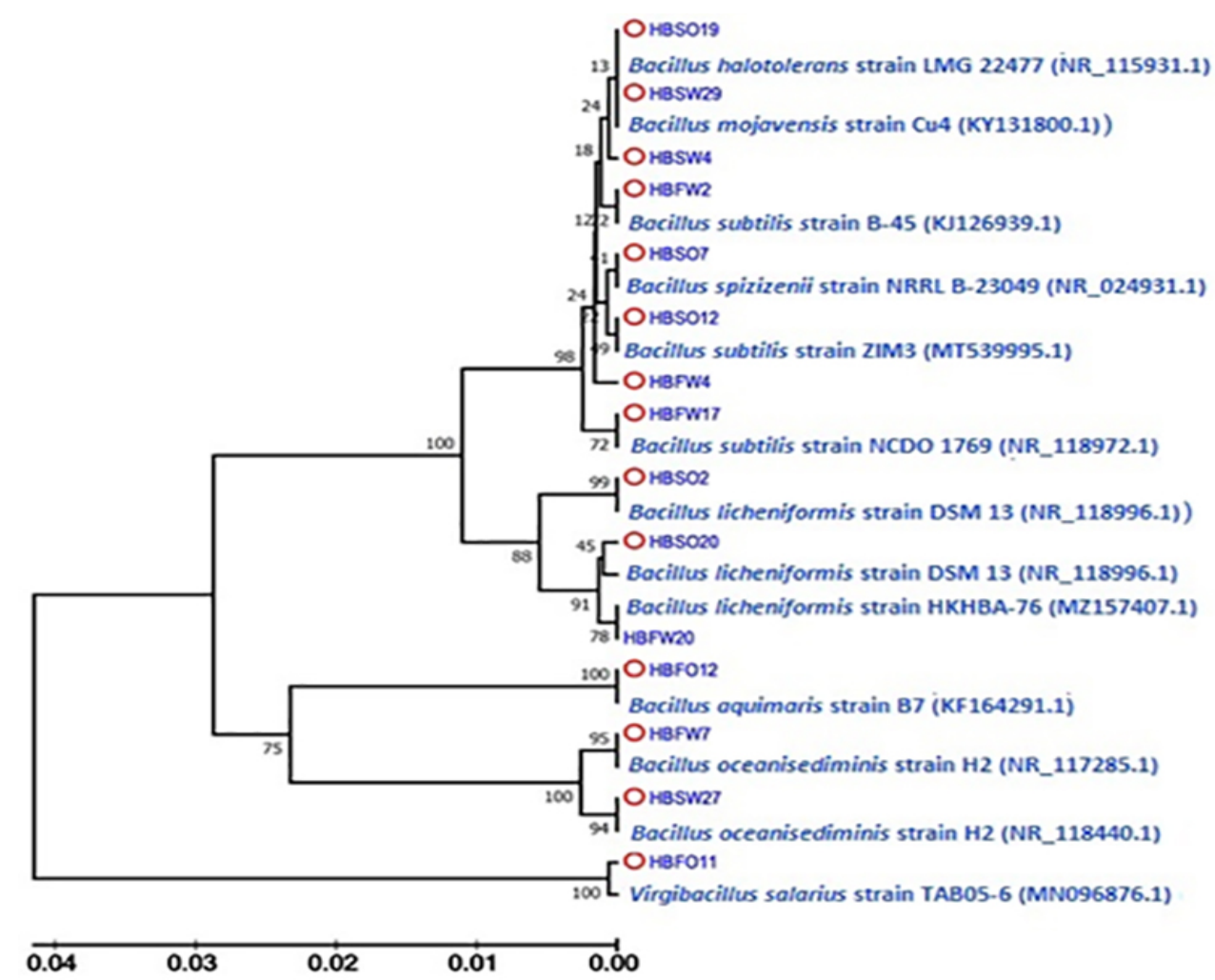

Figure 3:Tree of phylogenetic based on $16 \mathrm{~S}$ rRNA gene sequences analysis from the halophilic bacteria isolated from Sidi El Abed and Sidi Moussa salterns. The red circle indicates the 15 strains analyzed. Bar, 0.01 substitutions per nucleotide position.

\subsection{Effect of physico-chemical conditions on bacterial strain growth}

The growth of bacterial strains under different physico-chemical conditions is reported in Table 2. All strains were able to grow optimally on medium with $5 \% \mathrm{NaCl}$, thirteen of them were able to grow on medium with $10 \% \mathrm{NaCl}$,only two strains belonging to $B$. subtilis were able to tolerate a concentration of $15 \%$ and no strain tolerate $20 \% \mathrm{NaCl}$. These results indicated that these strains are moderately halophilic as classified byKushner and Kamekura[19].

The results of the Influence of temperature of incubation showed that all strains were able to grow at $30^{\circ} \mathrm{C}$ and $50^{\circ} \mathrm{C}$ except three strains, that could not tolerate $50^{\circ} \mathrm{C}$, and only two strains: C.oceanisediminis HBSW27 and B.aquimaris HBFO12 were able to grow at $10^{\circ} \mathrm{C}$. Hence, the strains identified in this study are designated as mesophilic and, in some cases, thermotolerant. Moreover, all isolates studied were tolerant of neutral $\mathrm{pH}$, with 8 strains designated as acid-tolerant and 8 strains also considered alkaline-tolerant [20]. The pH tolerance of V.salarius HBFO11 and B.subtilis HBSO7 was quite wide (4.5 to 9.4).

The physico-chemical characterization of the isolated bacteria proved the great biotechnological potential of our strains, due to their ability to tolerate other extreme conditions than salt.

Table 2: Growth of halophilic bacteria identified at different physico-chemical conditions. 


\begin{tabular}{|c|c|c|c|c|c|c|c|c|c|c|c|}
\hline \multirow[t]{2}{*}{ Species } & \multirow[t]{2}{*}{ Strains } & \multicolumn{4}{|c|}{$[\mathrm{NaCl}]$} & \multicolumn{3}{|c|}{$\mathrm{pH}$} & \multicolumn{3}{|c|}{ Temperature } \\
\hline & & $5 \%$ & $10 \%$ & $15 \%$ & $20 \%$ & 4.5 & 7.2 & 9.4 & $10{ }^{\circ} \mathrm{C}$ & $30{ }^{\circ} \mathrm{C}$ & $50^{\circ} \mathrm{C}$ \\
\hline V.salarius & HBFO11 & ++ & + & - & - & +++ & ++ & ++ & - & +++ & ++ \\
\hline \multirow[t]{2}{*}{ C. oceanisediminis } & HBSW27 & ++ & + & - & - & - & ++ & - & - & ++ & + \\
\hline & HBFW7 & +++ & - & - & - & - & +++ & + & + & +++ & - \\
\hline \multirow[t]{4}{*}{ B.subtilis } & HBFW4 & +++ & ++ & - & - & ++ & ++ & - & - & ++ & ++ \\
\hline & HBFW17 & +++ & ++ & - & - & +++ & +++ & - & - & +++ & +++ \\
\hline & HBSO12 & +++ & ++ & - & - & ++ & +++ & + & - & +++ & - \\
\hline & HBFW2 & +++ & ++ & + & - & +++ & +++ & - & - & +++ & +++ \\
\hline B.spizizeni & HBSO7 & ++ & ++ & + & - & +++ & ++ & ++ & - & ++ & ++ \\
\hline B.mojavensis & HBSW4 & +++ & + & - & - & - & +++ & ++ & - & +++ & + \\
\hline \multirow[t]{3}{*}{ B.licheniformis } & HBSO20 & ++ & ++ & - & - & - & ++ & ++ & - & ++ & +++ \\
\hline & $\mathrm{HBSO} 2$ & +++ & ++ & - & - & - & +++ & ++ & - & +++ & +++ \\
\hline & HBFW20 & ++ & ++ & - & - & + & ++ & - & - & ++ & +++ \\
\hline \multirow[t]{2}{*}{ B.halotolerans } & HBSO19 & +++ & ++ & - & - & + & ++ & ++ & - & ++ & ++ \\
\hline & HBSW29 & ++ & - & - & - & - & ++ & - & - & ++ & + \\
\hline B.aquimaris & HBFO12 & ++ & ++ & - & - & - & ++ & - & + & ++ & - \\
\hline
\end{tabular}

Symbols: + growth; - no growth.

\subsection{Hydrolytic activities of halophilic bacteria strains}

The enzymatic activity results revealed that all identified strains were capable of producing at least one extracellular hydrolytic enzyme. Indeed, nine strains produce amylase, six strains produce cellulase, thirteen strains produce DNase, eleven strains produce lipase, and eight strains produce protease. The results of the combined hydrolytic enzyme activities show that seven strains (HBFO12, HBSO20, HBSW4, HBSO12, HBFW4, HBFW17, HBFO11) were able to produce four hydrolytic activities, four strains (HBSO2, HBFW2, HBFW7, HBSW27) showed three hydrolytic activities, three strains (HBSO19, HBFW20, HBSO7) displayed two hydrolytic activities and one strain (HBSW29) had one hydrolytic activity (Table 3 ).

The current study indicated that DNase was the most frequent activity, followed by lipase, amylase, protease and cellulase activities respectively. In a similar study, Moreno et al. [21]investigated the ability of halophilic bacteria to produce various extracellular hydrolytic enzymes (lipase, protease, DNase, amylase, pullulanase and xylanase) in the Atacama Desert, and also found that DNase producers were the most abundant isolates.In contrast, Kaitouni et al.[22] found that cellulase was the most represented enzyme activity among halophilic bacteria isolated from hypersaline environments of the pre-Rif region (Morocco). Indeed, the difference in bacterial diversity between the hypersaline environments of northern [22] and northwestern Morocco (current study) could be attributed to the fact that the two studies have only one species in common(B. subtilis).

Table 3: Hydrolytic activity of halophilic bacteria strains. 


\begin{tabular}{|c|c|c|c|c|c|c|}
\hline \multirow[t]{2}{*}{ Species } & \multirow{2}{*}{$\begin{array}{l}\text { Strain } \\
\text { Number }\end{array}$} & \multicolumn{5}{|c|}{ Hydrolytic activity (mm) } \\
\hline & & Lipase & Cellulase & Protease & Amylase & Dnase \\
\hline V.salarius & HBFO11 & 1 & 8 & 0 & 4 & 2 \\
\hline \multirow{2}{*}{ C.oceanisediminis } & HBSW27 & 0 & 4 & 0 & 1 & 14 \\
\hline & HBFW7 & 0 & 6 & 0 & 4 & 10 \\
\hline \multirow{4}{*}{ B. subtilis } & HBFW4 & 3 & 0 & 5 & 4 & 3 \\
\hline & HBFW17 & 3 & 0 & 4 & 4 & 1 \\
\hline & HBSO12 & 0 & 8 & 8 & 8 & 4 \\
\hline & HBFW2 & 12 & 0 & 1 & 0 & 8 \\
\hline B.spizizenii & HBSO7 & 4 & 0 & 0 & 0 & 4 \\
\hline B.mojavensis & HBSW4 & 10 & 4 & 0 & 1 & 8 \\
\hline \multirow{3}{*}{ B.licheniformis } & HBSO20 & 6 & 12 & 0 & 4 & 2 \\
\hline & HBSO2 & 3 & 0 & 1 & 0 & 4 \\
\hline & HBFW20 & 0 & 0 & 2 & 0 & 1 \\
\hline \multirow{2}{*}{ B.halotolerans } & HBSO19 & 4 & 0 & 1 & 0 & 0 \\
\hline & HBSW29 & 2 & 0 & 0 & 0 & 0 \\
\hline B.aquimaris & HBFO12 & 1 & 0 & 6 & 2 & 12 \\
\hline
\end{tabular}

Note: After incubation, the hydrolytic activity of each strain was measured as follows: Colony diameter - Halo diameter ( $\mathrm{mm})$.

The enzyme profiles for each species are presented in Table 3. All four strains belonging to B.subtiliswere capable of producing protease and DNase, three were lipase and amylase producers, and only one showed cellulase activity. Furthermore, B. subtilis HBSO12 showed great biotechnological potential, due to its high capacity to produce all the enzymes studied except lipase, and it is also the most protease-producing strain. Moreover, several studies have already proven that $B$. subtilis is a source of extracellular protease [23-26]. In addition, B. subtilishas been previously reported as an excellent producer of different extracellular hydrolytic enzymes, including cellulase, amylase, lipase and protease, with satisfactory characteristics for many industrial applications such as industrial fermentation of sugars, soybeans and tobacco[27-30]. Indeed, the B. subtilis strains isolated in this study were able to produce all the extracellular enzymes already mentioned.

B. licheniformis, the second most represented species in this study, displayed low enzymatic activity, except for strain HBSO20 which showed the highest productivity of cellulase. This strain is a promising producer of other enzymes besides cellulase compared to previous studies $[31,32]$. It also showed the ability to grow significantly at temperatures of $50^{\circ} \mathrm{C}$ and tolerance to alkaline $\mathrm{pH}$.Accordingly, these characteristics give the strain HBSO20 the potential to produce thermostable and halo-alkaline enzymes for use in industries that require extreme conditions.

C.oceanisediminis,B.aquimaris, B.halotolerans, B.mojavensis, and B.spizizenii are among the species identified in this study and have already demonstrated technological interest in previous studies. Firstly,C.oceanisediminis the species that produced the most Dnase in this study has been previously identified as a source of these extracellular enzymes.[33, 21].secondly, the B.aquimaris species, which was shown to be capable of producing amylase, protease, Dnase, and lipase in this study, has previously demonstrated its biotechnological importance in several studies[34, 35]. Thirdly, both strains identified as B.halotoleranswere capable of producing a lipase. Moreover, in a recent study, a lipase from this species was characterized and showed properties suitable for various industrial applications [36]. Fourthly, B.mojavensis HBSW4, the second most lipase-producing strain in this study, has also shown the ability to secrete Dnase, cellulase and amylase.Similarly,Moreno et al [21] had previously reported the potential of this species to 
produce lipase and Dnase. Fifthly, B.spizizenii has shown the ability to produce only lipase and Dnase.On the other hand, a recent study reported the ability of this species to produce cellulase and protease, which has not been demonstrated by our strain [37].Lastly, HBFO11 identified as a member of V.salarius showed the ability to produce all hydrolases studied, except protease. As well, according to a similar study, this species was reported as a producer of cellulase and nuclease[38].

The species isolated in this study were previously isolated from several environmental extremes and showed high enzymatic potential as listed in table 4.

Table 4: Previous studies that isolated the same species as the present study with hydrolase activities

\begin{tabular}{|c|c|c|c|c|}
\hline Isolation Site & $\begin{array}{l}\text { Number of } \\
\text { identified } \\
\text { strains }\end{array}$ & $\begin{array}{l}\text { Species similar to the species } \\
\text { isolated in this study. (Number of } \\
\text { strains) }\end{array}$ & $\begin{array}{l}\text { Hydrolytic } \\
\text { Activity }\end{array}$ & References \\
\hline $\begin{array}{l}\text { Debagh Hot } \\
\text { (Algeria) }\end{array}$ & 41 & $\begin{array}{l}\text { B.mojavensis (16) } \\
\text { B.subtilis (3) } \\
\text { B.licheniformis (11) }\end{array}$ & $\begin{array}{l}\text { Not } \\
\text { determined }\end{array}$ & [39] \\
\hline $\begin{array}{l}\text { Mahala salt lake in Fars } \\
\text { province (southern Iran) }\end{array}$ & 13 & $\begin{array}{l}\text { B.aquimaris(1) } \\
\text { B.subtilis (2) }\end{array}$ & Lipase & {$[40]$} \\
\hline $\begin{array}{l}\text { Maharloo hypersaline } \\
\text { lake located in the south } \\
\text { of Shiraz, Iran. }\end{array}$ & 16 & B. subtilis (3) & Protease & [23] \\
\hline $\begin{array}{l}\text { saline lakes ecosystems } \\
\text { (Algeria) }\end{array}$ & 74 & $\begin{array}{l}\text { C.oceanisediminis (1) } \\
\text { B.subtilis (1) } \\
\text { B.spizizenii (1) } \\
\text { B.halotolerans, (3) } \\
\text { V.salarius (4) }\end{array}$ & $\begin{array}{l}\text { Amylase } \\
\text { Cellulase } \\
\text { Esterase } \\
\text { Gelatinase } \\
\text { Inulinase, } \\
\text { Nuclease } \\
\text { Pectinase } \\
\text { Protease } \\
\text { Xylanase. }\end{array}$ & [41] \\
\hline $\begin{array}{l}\text { Natural and artificial } \\
\text { hypersaline } \\
\text { environments in the } \\
\text { pre-Rif region } \\
\text { (northern Morocco) }\end{array}$ & 56 & B. subtilis (6) & $\begin{array}{l}\text { Cellulase } \\
\text { Amylase } \\
\text { Protease } \\
\text { Pectinase } \\
\text { Inulinase } \\
\end{array}$ & {$[22]$} \\
\hline $\begin{array}{l}\text { Marsh and two salterns } \\
\text { from Lower } \\
\text { Loukkos(west of } \\
\text { Morocco) }\end{array}$ & 122 & $\begin{array}{l}\text { C.oceanisediminis (8) } \\
\text { B.licheniformis }(1) \\
\text { B.aquimaris (32) }\end{array}$ & $\begin{array}{l}\text { Protease } \\
\text { Cellulase } \\
\text { Amylase } \\
\text { DNase }\end{array}$ &.$[33]$ \\
\hline $\begin{array}{l}\text { Atacama Desert in } \\
\text { northern Chile }\end{array}$ & 25 & $\begin{array}{l}\text { C.oceanisediminis (1) } \\
\text { B.mojavensis (1) } \\
\text { B.licheniformis (1) } \\
\text { B.aquimaris (1) }\end{array}$ & $\begin{array}{l}\text { Protease } \\
\text { Lipase } \\
\text { Amylase } \\
\text { DNase } \\
\text { Pullulanase } \\
\text { Xylanase }\end{array}$ & {$[21]$} \\
\hline $\begin{array}{l}\text { This study: The Sidi } \\
\text { Moussa-Oualidia } \\
\text { complex, Morocco }\end{array}$ & 15 & $\begin{array}{l}\text { V.salarius (1) } \\
\text { C.oceanisediminis(2) } \\
\text { B.subtilis (4) } \\
\text { B.spizizenii(1) } \\
\text { B.mojavensis(1) } \\
\text { B.licheniformis (3) } \\
\text { B.halotolerans(2) } \\
\text { B.aquimaris(1) }\end{array}$ & $\begin{array}{l}\text { Protease } \\
\text { Lipase } \\
\text { Amylase } \\
\text { DNase } \\
\text { Cellulase }\end{array}$ & \\
\hline
\end{tabular}

\section{Conclusion}


The study of the biodiversity of halophilic bacteria producing extracellular enzymes from the salines of Sidi Moussa and Sidi El Abed allowed the identification of 15 strains belonging to eight species ( V.salarius, C. oceanisediminis B. subtilis, B. spizizenii, B. mojavensis , $B$. licheniformis $B$. halotolerans and $B$. aquimaris) and showed the presence of higher hydrolase activity in all identified halophilic species. Furthermore, the growth of bacterial strains under different physicochemical conditions showed a great diversity within the same species. Therefore, these properties make our isolated strains potentially useful in industrial processes where extreme conditions would inhibit ordinary enzymes. Indeed, to explore the diversity of halophilic bacteria in Morocco, other research is currently underway to screen halophilic bacteria producing extracellular hydrolytic enzymes in other Moroccan hypersaline environments.

\section{References}

1. A. Ventosa, J.J. Nieto, and A. Oren. Microbiol. Mol. Biol. Rev. 62(2): p. 504-544 (1998).

2. R. Margesin and F. Schinner. Extremophiles. 5(2): p. 73-83 (2001).

3. N. Kulkarni, A. Shendye, and M. Rao. FEMS microbiology reviews. 23(4): p. 411-456 (1999).

4. F. Niehaus, C. Bertoldo, M. Kähler, and G. Antranikian. Applied microbiology and biotechnology. 51(6): p. 711-729 (1999).

5. A. Pandey, P. Selvakumar, C.R. Soccol, and P. Nigams. Current science: p. 149162 (1999).

6. J. Gomes and W. Steiner. Food technology and Biotechnology. 42(4): p. 223-225 (2004).

7. S. Mechri, K. Bouacem, M. Amziane, A. Dab, F. Nateche, and B. Jaouadi. BioMed Research International. 2019 (2019).

8. C. Sánchez-Porro, S. Martin, E. Mellado, and A. Ventosa. Journal of applied microbiology. 94(2): p. 295-300 (2003).

9. A. Oren. Environmental technology. 31(8-9): p. 825-834 (2010).

10. W.G. Weisburg, S.M. Barns, D.A. Pelletier, and D.J. Lane, 16S ribosomal DNA amplification for phylogenetic study. Journal of bacteriology. 173(2): p. 697 (1991).

11. S. Kumar, G. Stecher, M. Li, C. Knyaz, and K. Tamura,. Molecular biology and evolution. 35(6): p. 1547 (2018).

12. L. Prescott, J. Harley, and D. Klein. McGraw-Hill Higher education Companies. Inc., New York (2003).

13. N. Sadfi-Zouaoui, B. Essghaier, M. Hajlaoui, M.-L. Fardeau, J. Cayaol, B. Ollivier, and A. Boudabous. Journal of Phytopathology. 156(1): p. $42-52$ (2008).

14. C.D. Jeffries, D.F. Holtman, and D.G. Guse. Journal of Bacteriology. 73(4): p. 590 (1957).

15. D.A. Cowan. Biotechnology, the Science and the Business: p. 311-340 (1991).

16. G. Sierra. Antonie van Leeuwenhoek. 23(1): p. 15-22 (1957).

17. S. Patel and R.S. Gupta. International journal of systematic and evolutionary microbiology. 70(1): p. 406-438 (2020).

18. C.A. Dunlap, M.J. Bowman, and D.R. Zeigler. Antonie van Leeuwenhoek. 113(1): p. 1-12 (2020).

19. D.J. Kushner and M. Kamekura. Halophilic Bact. 1: p. 109-140 (1988).

20. H. Saito and H. Kobayashi. Science progress. 86(4): p. 271-282 (2003).

21. M. Moreno, F. Piubeli, M. Bonfa, M. García, L. Durrant, and E. Mellado. Journal of applied microbiology. 113(3): p. 550-559 (2012). 
22. L.B.D. Kaitouni, J. Anissi, K. Sendide, and M. El Hassouni. Annals of Microbiology. 70(1): p. 1-15 (2020).

23. Y. Ghasemi, A.S. RSOUL, A. Ebrahiminezhad, A. Kazemi, M. Shahbazi, and N. Talebnia, Screening and isolation of extracellular protease producing bacteria from the Maharloo Salt Lake. (2011).

24. W. Kim and S. Kim. Journal of food biochemistry. 29(5): p. 591-610 (2005).

25. T. Maruthiah, P. Esakkiraj, G. Prabakaran, A. Palavesam, and G. Immanuel,. Biocatalysis and Agricultural Biotechnology. 2(2): p. 116-119 (2013).

26. N. Nisha and J. Divakaran. African Journal of Biotechnology. 13(16) (2014).

27. Y. Bakri, S. Elkhouri, M. Harba, and Y. Akeed. Biological Sciences-PJSIR. 63(2): p. 113-118 (2020).

28. J. Dai, A. Dong, G. Xiong, Y. Liu, M.S. Hossain, S. Liu, N. Gao, S. Li, J. Wang, and D. Qiu. Frontiers in Microbiology. 11(1539) (2020).

29. T. Eggert, U. Brockmeier, M.J. Dröge, W.J. Quax, and K.-E. Jaeger. FEMS Microbiology Letters. 225(2): p. 319-324 (2003).

30. T. Peláez, R. Guillermo, and C. Yuliet. Acta Microscopica. 29(5) (2020).

31. F. Azadian, A. Badoei-Dalfard, A. Namaki-Shoushtari, and M. Hassanshahian,. Molecular Biology Research Communications. 5(3): p. 143 (2016).

32. S. Shajahan, I.G. Moorthy, N. Sivakumar, and G. Selvakumar. Journal of King Saud University-Science. 29(3): p. 302-310 (2017).

33. I. Berrada, A. Willems, P. De Vos, E. El Fahime, J. Swings, N. Bendaou, M. Melloul, and M. Amar. African Journal of Microbiology Research. 6(10): p. 24192434 (2012).

34. P. Shivanand and G. Jayaraman. Process Biochemistry. 44(10): p. 1088-1094 (2009).

35. N. Trivedi, V. Gupta, M. Kumar, P. Kumari, C. Reddy, and B. Jha. Chemosphere. 83(5): p. 706-712 (2011).

36. S.C. Podeti, Ramya \& Alpula, Nagaraju \& Lapaka, Suresh. International Journal of Pharmacy and Biological Sciences.: p. 1-16 (2020).

37. F. Masmoudi, S. Tounsi, C.A. Dunlap, and M. Trigui. Plant Cell Reports: p. 1-15 (2021).

38. T. Menasria, M. Monteoliva-Sánchez, L. Benammar, M. Benhadj, A. Ayachi, H. Hacène, A. Gonzalez-Paredes, and M. Aguilera. World Journal of Microbiology and Biotechnology. 35(9): p. 132 (2019).

39. M. Arab, S. Bakour, R. Lalaoui, N. Aissaoui, F. Nas, A. Hoceini, P.-E. Fournier, and N. Klouche-Khelil. Geomicrobiology Journal. 36(2): p. 137-147 (2019).

40. Y. Ghasemi, S. Rasoul-Amini, A. Kazemi, G. Zarrini, M. Morowvat, and M. Kargar, Isolation and characterization of some moderately halophilic bacteria with lipase activity. Microbiology. 80(4): p. 483 (2011).

41. T. Menasria, M. Monteoliva-Sánchez, L. Benammar, M. Benhadj, A. Ayachi, H. Hacène, A. Gonzalez-Paredes, and M. Aguilera. World Journal of Microbiology and Biotechnology. 35(9): p. 1-16 (2019). 